\title{
Biomedical Sciences
}

Citation: Mendoza D, Egea E, Garavito $\mathrm{G}$, et al. Immunological detection in indoor environments of house dust mite allergens using avian antibodies - IgY: An innovative tool. Rev. Acad. Colomb. Cienc. Ex. Fis. Nat. 45(175):366-376, abril-junio de 2021. doi: https://doi. org/10.18257/raccefyn.1304

Editor: Luis Fernando García

*Corresponding autor: Dary Mendoza Meza;

dary_mendoza@yahoo.com; darymendoza@mail.uniatlantico.edu.co

Received: September 19, 2020

Accepted: March 31, 2021

Published: June 17, 2021

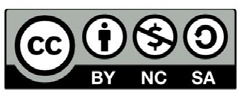

Este artículo está bajo una licencia de Creative Commons ReconocimientoNoComercial-Compartir Igual 4.0 Internacional
Original article

\section{Immunological detection in indoor environments of house dust mite allergens using avian antibodies - IgY: An innovative tool}

\author{
Detección inmunológica de alérgenos de ácaros del polvo \\ doméstico en ambientes interiores utilizando anticuerpos \\ aviares - IgY: una herramienta innovadora

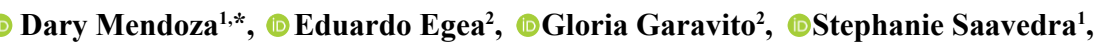

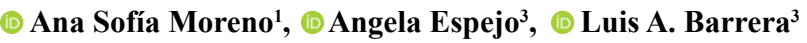 \\ ${ }^{1}$ Grupo de Investigación en Productos Naturales y Bioquímica de Macromoléculas, Facultad de Ciencias \\ Básicas, Universidad del Atlántico, Puerto Colombia, Atlántico, Colombia \\ ${ }^{2}$ Grupo de Investigación en Inmunología y Biología Molecular, Departamento de Ciencias de la Salud, \\ Universidad del Norte, Puerto Colombia, Atlántico, Colombia \\ ${ }^{3}$ Instituto de Errores Innatos del Metabolismo, Pontificia Universidad Javeriana, Bogotá D.C., Colombia
}

\begin{abstract}
IgY technology has emerged as an alternative for antibody production with immunodiagnostic purposes. Recently, we produced avian antibodies (IgY) against group-1 dust mite allergens of Dermatophagoides $s p(D s p)$ and Blomia tropicalis $(B t)$. These allergens are important sensitizing agents that contribute to the pathophysiology of allergy rhinitis and asthma in patients living in tropical areas. The purpose was to explore the utility of IgY for detecting dust mite allergens in indoor environments. We collected 100 samples of dust from mattresses of asthmatic individuals living in two cities on the Colombian Caribbean coast. We used an in-home indirect enzyme-linked immunosorbent assay (ELISA) to detect the mite allergens using two IgYs (IgY-PO2 and IgY-PO4). We determined the IgY detection limit using whole body extracts of $D s p$ and $B t$; likewise, IgY specificity was probed against one crude extract of cockroach, as well as the precision and accuracy of measurements. Both antibodies recognized allergens in the mite extracts, even at the lowest tested concentration $(0.05 \mu \mathrm{g} / \mathrm{mL})$; none reacted with the cockroach extract demonstrating their specificity for mite allergens. On the other hand, IgY-PO4 showed the best precision (intra-assay: $\mathrm{CV}<6.99 \%$; inter-assay: $\mathrm{CV} \leq 8.71 \%$ ) and an accuracy: $80.62-100.39 \%$. Allergen levels detected were consistent with the mite density present in the dust samples. We confirmed the usefulness of IgY-PO2 and IgYPO4 for detecting dust mite pollution in indoor environments.
\end{abstract}

Keywords: Immunoassay; ELISA; IgY antibodies; House dust mites; Allergens.

\section{Resumen}

La tecnología de anticuerpos aviares (IgY) ha surgido como una alternativa para la producción de anticuerpos con fines de inmunodiagnóstico. Recientemente produjimos IgY contra alérgenos de ácaros del polvo del grupo 1 de Dermatophagoides $s p(D s p)$ y Blomia tropicalis (Bt). Estos alérgenos son importantes agentes de sensibilización que contribuyen a la fisiopatología de la rinitis alérgica y el asma en pacientes asentados en áreas tropicales. El propósito del presente estudio fue explorar la utilidad de los IgY para detectar alérgenos de ácaros en ambientes interiores. Se recolectaron 100 muestras de polvo de colchones de asmáticos residentes en dos ciudades de la costa Caribe colombiana. Se utilizó un ensayo inmunoabsorbente indirecto ligado a enzimas (ELISA) casero para detectar los alérgenos de ácaros usando dos IgY (IgY-PO2 e IgYPO4). Se determinó el límite de detección de los IgY utilizando extractos de cuerpo entero de $D s p$ y $B t$; asimismo, se indagó la especificidad de los IgY frente a un extracto crudo de cucaracha y 
se determinaron la precisión y la exactitud de las mediciones. Ambos anticuerpos reconocieron alérgenos en los extractos de ácaros, incluso en la concentración más baja probada $(0,05 \mu \mathrm{g} /$ $\mathrm{mL}$ ), y ninguno reaccionó con el extracto de cucaracha, lo que demuestra su especificidad para los alérgenos de ácaros. Por otro lado, el IgY-PO4 tuvo los mejores resultados de precisión (intraensayo: $\mathrm{CV}<6,99 \%$; interensayo: $\mathrm{CV} \leq 8,71 \%$ ) y exactitud: 80,62 a 100,39\%. Los niveles de alérgenos detectados fueron consistentes con la densidad de ácaros en las muestras. Este estudio destaca la aplicación de IgY-PO2 e IgY-PO4 para la detección de la contaminación por ácaros en ambientes interiores.

Palabras clave: Inmunoensayo; ELISA; Anticuerpos IgY; Ácaros del polvo doméstico; Alérgenos.

\section{Introduction}

Respiratory allergy frequency and etiological complexity are growing in Latin American countries. These allergies involve the interaction of genetic and environmental factors (Drake, et al., 2008; Mukherjee \& Zhang, 2011; Asher, et al., 2020). Two transversal studies conducted in six Colombian cities have shown a clear increase in the cumulative prevalence of asthma symptoms over the last decade (Dennis, et al., 2004; Dennis, et al., 2012) reporting a total prevalence of $12.1 \%$ in the country and of $14.5 \%$ in the city of Barranquilla on the Caribbean coast (Dennis, et al., 2012).

In tropical countries, asthma cases are strongly associated with exposure to indoor allergens whose main source is house dust mites such as B. tropicalis (Bt) and Dermatphagoides sp (Dsp) (Milián \& Díaz, 2004; Andiappan, et al., 2014). In fact, there is a dose-response relationship between exposure to those allergens and the risk of developing allergen sensitization (Marks, 1998; Huss, et al., 2011). Epidemiological evidence shows that continual exposure to allergens is a risk factor for the development of asthma. Accordingly, the promotion of interventions to reduce allergen exposure, especially in indoor environments, has recently increased (Winn, et al., 2016; Vojta, et al., 2001; Paufler, et al., 2001). In most cases, a reduction in allergen exposure has resulted in clinical benefits for asthma patients with a significant impact in terms of public health as well (Morgan, et al., 2004; Halken, 2004).

Asthma poses a considerable social and economic burden on patients and their families (Kamble \& Bharmal, 2009). A study based on the Medical Expenditure Panel Survey (MEPS) findings estimated asthma-related direct and indirect medical costs in the USA in 2007: Annual direct costs per person were estimated at US\$1,999.17, hospitalization costs at US\$ 703.39, and drug-prescription costs at US\$ 624.81 while average annual indirect costs per person amounted to another US\$ 628.84 (Rappaport \& Bonthapally, 2012). In Colombia, studies on asthma-related direct and indirect costs have also shown the high economic burden associated with this disease (Londoño-Trujillo \& Celis-Preciado, 2016; Rodríguez-Martínez, et al., 2017).

The development of high-quality antibodies and detection reagents for immunoassays is of great importance for diagnosing allergic diseases such as asthma and allergic rhinitis as they can quickly identify specific allergen levels in home environments, a primordial step to control them adequately. The concept of "low allergen levels for life" is frequently used in Europe and many tools already exist in the market for allergen detection and monitoring (Portnoy, et al., 2013). Unfortunately, the majority of these are not readily available for the asthmatic population of underdeveloped countries.

Blomia tropicalis (Bt) and Dermatophaglides sp (Dsp) are the most clinically important mite species in the tropic. Currently, commercially available antibodies for mite-allergen detection in indoor environments are mainly mouse and rabbit IgG class antibodies. Companies such as Indoor Biotechnologies (Charlottesville, Virginia) produce monoclonal and polyclonal IgG antibodies against the major allergens of $D$. pteronyssinus (Der p 1 and Der p 2), D. farinae (Der $\mathrm{f} 1$ and Der $\mathrm{f} 2$ ), and B. tropicalis (Blo t 5). Immunoassays based on IgG-antibodies (Multiplex Array for Indoor Allergens MARIA ${ }^{\circledR}$ from Indoor Biotechnologies and Dust Mite Screen Check from Environmental 
Diagnostics Laboratory, Clearwater, Florida) are also available for dust-samples analysis in the laboratory (Portnoy, et al., 2013). To the best of our knowledge, presently there are no commercially available IgY antibodies for the detection of house dust mite allergens.

Here, we show the utility of two polyclonal avian antibodies (IgY) for detecting $D s p$ and $B t$ allergens in house dust samples from two Colombian Caribbean cities. Our results evidenced that they may be used as immunoreagents for the primary detection of mite allergens. Future studies should explore the design and development of immunoassays for rapid and efficient detection of mite allergens based on IgY-PO2 and IgY-PO4 antibodies.

\section{Materials and methods}

\section{Antibodies}

Two polyclonal avian antibodies (IgY) from Hy Line Brown hen eggs were produced against non-glycosylated synthetic oligopeptides designed in silico based on sequences from dust mite group-1 allergens Bt (named PO2) and Dsp (named PO4) (Patent US9416163 B2) (Barrera, et al., 2016). We determined antibody titers by ELISA while in a previous study (Egea, et al., 2018), mite protein concentration and the ability of antibodies to recognize $B t$ and $D s p$ group-1 allergens had been determined by Western Blot.

\section{Mite extracts}

Whole body $D s p$ and $B t$ extracts were prepared from mite cultures done in the immunology and molecular biology laboratory at Universidad del Norte following the methodology previously described (Mendoza, et al., 2011) and then used to determine IgY-antibody detection limits and as a positive control in the ELISA assays. An allergenic extract from the cockroach Periplaneta americana $(P a)$ was used to evaluate IgY antibody specificity in the indirect ELISA (kindly donated by Dr. Enrique Fernández-Caldas, Scientific Director at Inmunotek, Spain). The total protein concentration in the Dsp extract was $1.42 \mathrm{mg} / \mathrm{mL}$, in the Bt extract, $1.67 \mathrm{mg} / \mathrm{mL}$, and in the Pa extract, $2.80 \mathrm{mg} / \mathrm{mL}$. All extract concentrations were determined using the Quick Start ${ }^{\mathrm{TM}}$ Bradford Protein Assay kit from Bio-Rad.

\section{House dust samples}

Samples were obtained from asthmatic people's homes in the metropolitan area of Barranquilla and Santa Marta, two Colombian cities on the Caribbean coast with a high prevalence of asthma symptoms (Dennis, et al., 2012; Mendoza, et al., 2008). We took all the samples from the mattresses of the asthmatic individuals' wooden beds participating in the study. Housing characteristics met public health criteria and the patients' indoor conditions corresponded to those required in primary and secondary care.

We collected 100 samples between March and September 2016 (50 samples from Barranquilla and 50 from Santa Marta). For the sampling, we used a Eureka ${ }^{\circledR}$ Mite II vacuum hoover (The Eureka ${ }^{\circledR}$ Company, Bloomington, IL) placing a 19 x 90 -mm nitrocellulose extraction cartridge (Whatman International Ltd., Maidstone, UK) at the end of the hoover extension tube and sealing the joint with a rubber ring. We hoovered a $2-\mathrm{m}^{2}$ area in each mattress at $0.5 \mathrm{~m}^{2} / \mathrm{min}$ according to the US EPA 747-R-95-001.14 protocol (Environmental Protection Agency - EPA, 1995). Extraction cartridges containing dust samples were stored in labeled plastic bags, sealed, and finally stored at $4{ }^{\circ} \mathrm{C}$ until their processing. We sieved the samples using a $500-\mu \mathrm{m}$ mesh and then analyzed them on the microscope to identify and quantify the mites as previously described (Acuña, et al., 2015). Briefly, $50 \mathrm{mg}$ of each sample were treated for 2 hours with a PBS (1X, pH 7,2) solution $(1: 1, \mathrm{v} / \mathrm{v})$ at $40^{\circ} \mathrm{C}$. Afterwards, mites were visualized using a Nikon SMZ-1 (4X) microscope, isolated with a fine needle, and fixed on slides for their identification using taxonomic keys (Collof \& Spieksma, 1992; Smiley \& Gorham, 1991). The number of $B t$ and Dsp (D. pteronyssinus and D. farinae) mites was determined by a standard method (Arlian, et al., 1999) and results were expressed as the number of mites per gram of dust (m.p.g). 


\section{Extraction of mite allergens from dust}

To determine the optimal time for dust extraction, we used a randomized complete block experimental design with five treatments and three blocks. We analyzed two dust samples, one with a low density of mites ( $<300$ m.p.g.) and the other with a high density of mites (>500 m.p.g.). We mixed $100 \mathrm{mg}$ of dust in $1 \mathrm{~mL}$ of PBS $1 \mathrm{X}$ for each sample. The extraction was performed at room temperature on a Gemini twin Shaking Water Bath (Robbins Scientific ${ }^{\circledR}$ ) at $60 \mathrm{rpm}$ for 30,15, 10, 5, and $2 \mathrm{~min}$. Dust extracts were centrifuged for $10 \mathrm{~min}$ at $5,000 \mathrm{x}$ g in a Beckman refrigerated centrifuge (GPR model). We collected the supernatants in Eppendorf vials and used them immediately to evaluate the mite allergen content by ELISA. The results were expressed in absorbance values at 450 $\mathrm{nm}$. Once the extraction time was determined, the same procedure was set up using the 100 samples whose dust mite densities and compositions had been previously determined through microscopy analysis.

\section{ELISA assay}

We conducted an exploratory study to detect the usefulness of IgYPO2 and IgYPO4 in the detection of Bt and Dsp allergens in 100 house dust samples. Mite allergens were detected by an indirect ELISA test as previously described (Barrera, et al., 2016; Egea, et al., 2018). We coated polystyrene plates with 96 wells (Nunc Maxisorp ${ }^{\circledR}$ ) with 100 $\mu \mathrm{L}$ of antigen (mite extracts or dust extracts) and incubated the plates in a wet chamber at room temperature for 18 hours. Unbound molecules were removed from the plate and each well was subsequently blocked with $200 \mu \mathrm{L}$ of blocking solution (PBS 1X, 0.05 $\% \mathrm{v} / \mathrm{v}$ Tween-20, and $5 \% \mathrm{w} / \mathrm{v}$ skimmed milk) for 2 hours. Each well was then washed three times with PBST (1X PBS, 0.05\% v/v Tween-20) using an RT-2600C microplate dishwasher (Rayto $\left.{ }^{\circledR}\right)$. Primary antibodies were then added for one hour $(100 \mu \mathrm{L}$ of $\operatorname{IgY}$ PO2 or IgY-PO4 at $1 \mu \mathrm{g} /$ well). We minimized non-specific binding using four PBST wash steps. We detected the IgY-allergen complex using $100 \mu \mathrm{l} /$ well of secondary IgG anti-chicken antibody conjugated with horseradish peroxidase (Promega G1351). The secondary antibody was diluted $1 / 2,000$ in antibody dilution buffer (1X PBS, $0.025 \%$ $\mathrm{v} / \mathrm{v}$ Tween-20 and $2.5 \% \mathrm{w} / \mathrm{v}$ skimmed milk). Subsequently, the plate was washed four times in PBST. The reaction was developed with $100 \mu \mathrm{L}$ of the peroxidase substrate and 3,3',5,5'-tetramethylbenzidine (Sureblue Reserve ${ }^{\mathrm{TM}}$ TMB Microwell Peroxidase Substrate). After $15 \mathrm{~min}$, the reaction was stopped with $1 \mathrm{~N} \mathrm{HCl}$, and the yellow color read at a $450 \mathrm{~nm}$ wavelength in a Synergy HTX (BioTek ${ }^{\circledR}$ Instruments, Inc.) multimodal plate reader. We used mite extracts at $1 \mu \mathrm{g} / \mathrm{mL}(0.1 \mu \mathrm{g} / \mathrm{well})$ as the positive control in the final dust samples analysis and a pool of dust samples obtained from new mattresses as the negative control. The cut-off point to differentiate between positive and negative samples was the arithmetic mean plus 3 standard deviations of negative controls. We diluted those samples with absorbance values $\geq 1.0$ at $450 \mathrm{~nm}\left(\mathrm{~A}_{450}\right)$. All samples, including controls, were analyzed in triplicate.

\section{Detection limit and specificity}

We defined the detection limit as the smallest amount of allergen detected by each antibody above the noise of the ELISA test; in this regard, we included several reactions with PBS 1X (without extract) and pre-immune antibody (with extracts) in each plate to detect the noise (Supplement 1). Besides, we prepared two-fold serial dilutions of the mite extracts in PBS 1X (range of total protein from $0.05-20 \mu \mathrm{g} / \mathrm{mL}$ equivalent to $5-2000 \mathrm{ng} /$ well) and then analyzed them. We also analyzed whole body $\mathrm{Pa}$ (cockroach) extracts to evaluate the specificity of the antibodies.

\section{Calibration curve}

We designed a standard curve in the ELISA linearity range for each antibody. For IgYPO2, we used known concentrations of $B t$ whole body extract total protein while for IgY-PO4, we used the $D s p$ whole body extract and then we calculated allergens relative 
concentrations in the dust samples through the standard curves, whereas allergen levels were calculated using equation 1 (Eq. 1), and expressed in $\mu \mathrm{g}$ of allergens per gram of dust $(\mu \mathrm{g} / \mathrm{g})$.

$$
\text { Allergen levels }(\mu \mathrm{g} / g)=\frac{C \times F \times V}{M} \quad \text { Eq. } 1
$$

where $\mathrm{C}$ is the relative allergen concentration $(\mu \mathrm{g} / \mathrm{mL})$ calculated through the standard curve, $\mathrm{F}$, the dilution factor of the dust extract in the ELISA test, $\mathrm{V}$, the volume of dust extract $(1 \mathrm{~mL})$, and $\mathrm{M}$, the amount of dust sample in the extract $(0.1 \mathrm{~g})$.

\section{Precision and accuracy test}

Precision was determined by measuring the allergen levels of the same sample during five days (intertest) in five replicates (intratest) applying the same experimental procedure under predetermined conditions. For this test, we selected three dust samples with different mite densities at random. We calculated the results, expressed as a coefficient of variation (CV), using the following equation (Eq. 2).

$$
\% C V=(\text { Standard deviation /arithmetic mean }) \times 100 \quad \text { Eq. } 2
$$

The accuracy was evaluated through a recovery test in which three dust samples from new mattresses were spiked with a known concentration $(1 \mu \mathrm{g} / \mathrm{mL})$ of $B t$ and $D s p$ whole body extract for IgY-PO2 and IgY-PO4, respectively. We calculated the accuracy using the following equation (Eq. 3).

$$
\text { Accuracy }=\frac{(X-Y)}{Z}=\frac{W}{Z} \times 100 \text { Eq. } 3
$$

where $\mathrm{X}$ is the allergen concentration $(\mu \mathrm{g} / \mathrm{mL})$ in spiked samples, $\mathrm{Y}$, the allergen concentration $(\mu \mathrm{g} / \mathrm{mL})$ in unspiked samples, $\mathrm{W}$, the difference between $\mathrm{X}$ and $\mathrm{Y}$, and $\mathrm{Z}$, the experimental concentration of mite extract added to the samples.

\section{Data analysis}

Results were expressed as averages, medians, standard deviations (SD), and minimum and maximum ranges. Differences between treatments were evaluated using a oneway variance analysis (ANOVA) with a significance level of 0.05 . Multiple (pair-wise) comparisons were done by Tukey's honestly significant difference test (Tukey's HSD) and results were presented as $95 \%$ confidence intervals $(95 \% \mathrm{CI})$. All statistical tests and plots were performed with the free access Software "R" (http://www.r-project.org).

\section{Ethical considerations}

This study was conducted according to the guidelines expressed in 1993 Resolution $\mathrm{N}^{\circ}$ 008430 issued by the Ministry of Health of Colombia and in Law 84 from 1989.

\section{Results}

\section{Mite allergen extraction}

Allergen extraction was not significantly influenced by the extraction time when considering samples with a mite density greater than 500 m.p.g. (p>0.05). In contrast, when considering samples with a low mite density $(<300$ m.p.g.), extraction times below 5 min significantly decreased allergen detection with IgY-PO2 (Figure 1). Therefore, the extraction time used for all the dust samples was $5 \mathrm{~min}$.

\section{Detection limit and specificity}

Both IgY-PO2 and IgY-PO4 antibodies recognized allergenic proteins from $D s p$ and $B t$ extracts, even at the lowest tested concentration of $0.05 \mu \mathrm{g} / \mathrm{mL}$ (equivalent to $500 \mathrm{ng} / \mathrm{g}$ of dust). On the other hand, a linearity range was observed between the allergen concentration and the absorbance values using IgY-PO2 $(0.05-1.5 \mu \mathrm{g} / \mathrm{mL}$ of $B t$ extract) and IgY-PO4 $(0.05-2 \mu \mathrm{g} / \mathrm{mL}$ of $D s p$ extract) (Figure 2). We used this result to establish the protein concentration range in the calibration curves for the allergen quantification in the dust samples. 

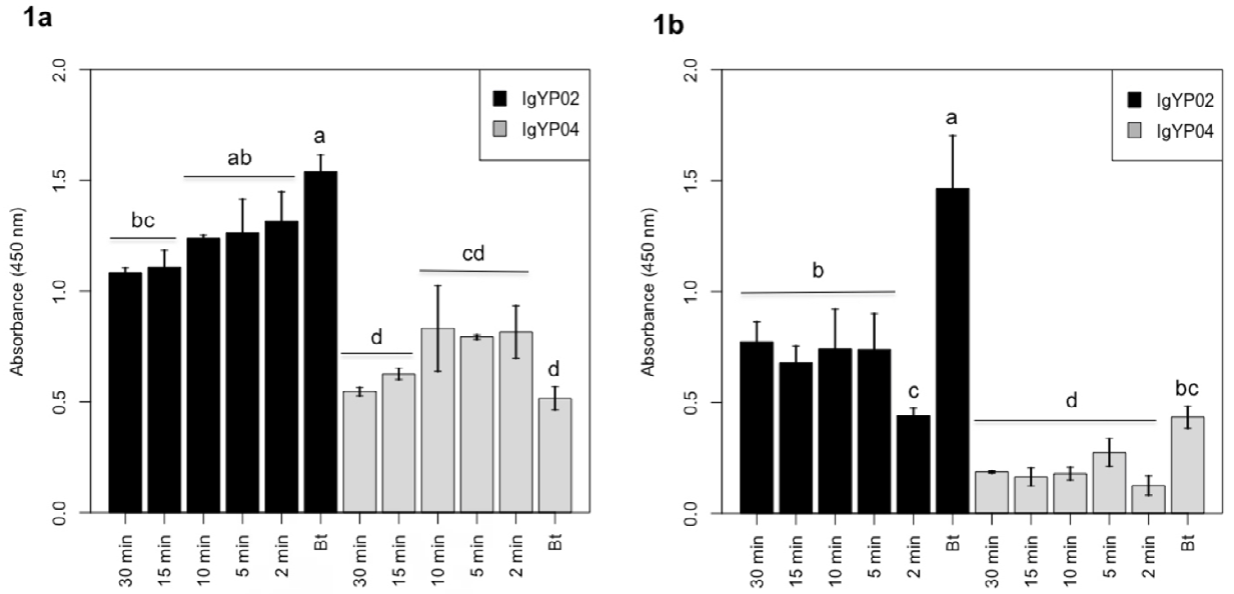

Figure 1. Extraction times of mite allergens proteins in dust samples with (1a) high densities of mites (> 500 m.p.g.) and (1b) low densities of mites (<300 m.p.g.). Allergens were detected with the polyvalent IgY antibodies IgY-PO2 and IgY-PO4 using ELISA. Each bar represents a different protein extraction time. Bt extract was used as a positive control at $1 \mu \mathrm{g} / \mathrm{mL}$. Results are expressed as average values $\pm 1 \mathrm{SD}$. Assays were performed in triplicate.

$\lg Y-P O 2$

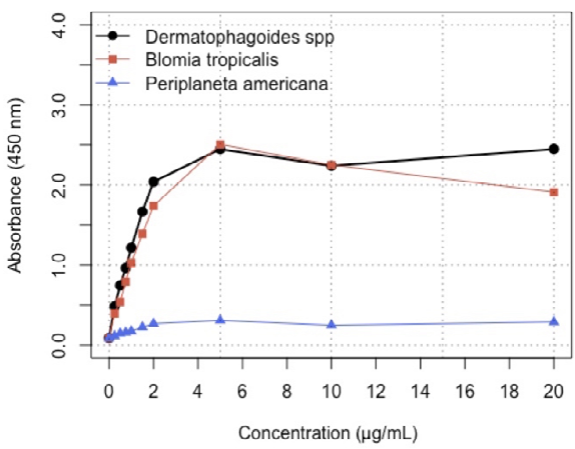

$\lg \mathrm{Y}-\mathrm{PO} 4$

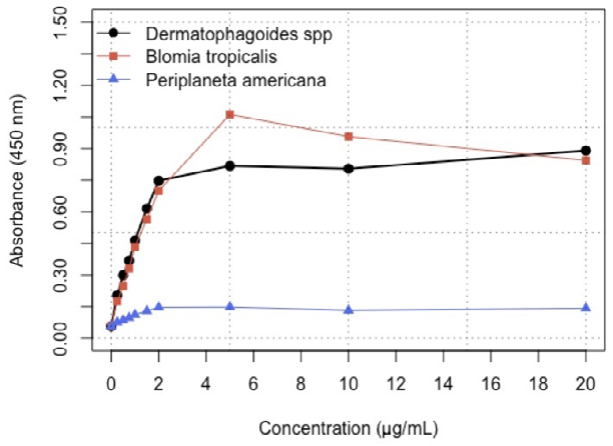

Figure 2. Detection limit of IgY-PO2 and IgY-PO4 antibodies. Different concentrations of Blomia tropicalis, Dermatophagoides sp, and Periplaneta americana extracts $(0.5-20 \mu \mathrm{g} / \mathrm{mL}$ equivalent to $0.05-2 \mu \mathrm{g} /$ well) were evaluated. Results are expressed as average values $\pm 1 \mathrm{SD}$.

An ANOVA showed a significant difference $(\mathrm{p}<0.005)$ between the reactivity of the antibodies towards the three different allergenic extracts $(B t>D s p>P a)$. The low reactivity of both IgY-PO2 and IgY-PO4 towards the cockroach extract is indicative of relevant antibody specificity.

\section{Allergen detection in dust samples}

Both antibodies were able to recognize allergenic proteins of $B t$ and $D s p$ in the dust samples collected in indoor environments. The allergens levels in the dust samples were determined by standard calibration curves with $B t$ and $D s p$ whole body extracts using IgY-PO2 and IgY-PO4, respectively (Supplement 2). On the other hand, we used dust samples collected from new mattresses to define the cut-off point of positive and negative samples at $\mathrm{A}_{450} \leq 0.145$ for IgY-PO2 and $\mathrm{A}_{450} \leq 0.122$ for IgY-PO4.

Table 1 shows the ELISA assay global results according to the sampling site (Barranquilla or Santa Marta). The dust samples collected in Barranquilla displayed higher levels of mite allergens in the ELISA experiments with IgY-PO2 and IgY-PO4, which is consistent with the higher total density of mites in these samples compared with the 
Santa Marta samples (mean difference $=378.57 ; 95 \% \mathrm{CI}=225.77-531.37, \mathrm{p}=3.8 \mathrm{E}-$ 06). Furthermore, IgY-PO4 showed greater reactivity when the samples collected in Barranquilla were analyzed (mean difference $=9.66 ; 95 \% \mathrm{CI}=5.95-13.37, \mathrm{p}=0.000$ ) compared with those from Santa Marta (mean difference $=1.86 ; 95 \% \mathrm{CI}=0.44-3.28 ; \mathrm{p}$ $=0.0107)$.

The correlation analysis of mite density and allergen levels detected with IgYPO2 and IgYPO4 showed a linear relationship that can be explained by a simple linear model $\left(\mathrm{Y}=\beta \mathrm{o}+\beta 1^{*} \mathrm{X}\right)$, i.e., an increase in the mite density of a dust sample results in an average increase in allergen levels corresponding to the value of the regression coefficient ( $\beta 1)$ (Supplement 3). Additionally, a high correlation coefficient $\left(\mathrm{R}^{2}=0.744\right)$ was observed in $B t$ and $D s p$ allergen levels, which could be attributed to the cross-reactivity of B. tropicalis with Dermatophagoides species (D. ptheronyssinus and D. farinae) (Cheong, et al., 2003; Liu, et al., 2019).

The results of the intertest and intratest precision experiments are presented in Table 2. The ELISA test with IgY-PO2 yielded coefficients of variation (CV) of 15.81 to $20.55 \%$ (intertest) and 3.05 to $10.94 \%$ (intratest). IgY-PO4 yielded CVs of 7.63 to $8.71 \%$ (intertest) and 6.18 to $6.99 \%$ (intratest).

The accuracy test confirmed that, regardless of the antibody used (IgY-PO2 or IgYPO4), there was no significant difference between spiked and unspiked samples with the mite extracts $(p>0.05)$. Furthermore, the percentage of allergen recovery was between 86.12 and $102.90 \%$ for IgY-PO2 and between 80.62 and $100.39 \%$ for IgY-PO4 (Table 3).

Table 1. Mite density and mite allergen levels (B. tropicalis and Dermatophagoides $s p$ ) in dust samples collected in Barranquilla $(\mathrm{N}=50)$ and Santa Marta $(\mathrm{N}=50)$

\begin{tabular}{lcccccccc}
\hline & $\begin{array}{c}\text { Sampling } \\
\text { site }\end{array}$ & Mean & $\begin{array}{c}\text { Minimum } \\
\text { value }\end{array}$ & $\begin{array}{c}\text { Maximum } \\
\text { value }\end{array}$ & $\begin{array}{c}\text { Mean } \\
\text { difference }\end{array}$ & LCL & UCL & p \\
\hline $\begin{array}{l}\text { Total mite } \\
\text { density }^{\mathrm{a}}\end{array}$ & Barranquilla & 638.02 & 50 & 1675 & 378.57 & 225.77 & 531.37 & $3.8 \mathrm{e}-06$ \\
\hline $\begin{array}{l}\text { IgY-PO2 } \\
(B t)^{\mathrm{b}}\end{array}$ & Santa Marta & 259.44 & 25 & 1000 & & & & \\
\hline $\begin{array}{l}\text { IgY-PO4 } \\
(D s p)^{\mathrm{c}}\end{array}$ & Santa Marta & 4.48 & 0.047 & 8.45 & 1.86 & 0.44 & 3.28 & 0.011 \\
\hline
\end{tabular}

${ }^{\text {a }}$ Numbers of mites per gram of dust (m.p.g.)

${ }^{\mathrm{b}} \mu \mathrm{g}$ of Blomia tropicalis $(B t)$ allergens per gram of dust $(\mu \mathrm{g} / \mathrm{g})$

${ }^{c} \mu \mathrm{g}$ of Dermatophagoides $s p(D s p)$ allergens per gram of dust $(\mu \mathrm{g} / \mathrm{g})$

LCL: Lower confidence limit; UCL: Upper confidence limit

Table 2. Coefficients of variation (CV) in the ELISA assay using IgY-PO2 and IgY-PO4 antibodies

\begin{tabular}{|c|c|c|c|c|c|c|}
\hline \multirow[t]{2}{*}{ Samples } & \multirow{2}{*}{$\begin{array}{l}\text { Mite density } \\
\text { (m.p.g.) }\end{array}$} & \multirow[t]{2}{*}{ Antibody (allergen) } & \multicolumn{4}{|c|}{ Allergen levels ( $\mu \mathrm{g} / \mathrm{g}$ of $\mathrm{dust})$} \\
\hline & & & Mean ${ }^{\mathrm{a}}$ & SD $^{\mathbf{b}}$ & $\mathbf{C V}^{\mathrm{c}}$ & $\mathbf{C V}^{\mathrm{d}}$ \\
\hline \multirow{2}{*}{1} & \multirow{2}{*}{ Low } & IgY-PO2 (Bt) & 9.02 & 1.85 & 20.55 & 10.77 \\
\hline & & IgY-PO4 (Dsp) & 6.97 & 0.55 & 7.83 & 6.18 \\
\hline \multirow{2}{*}{2} & \multirow{2}{*}{ Average } & IgY-PO2 (Bt) & 15.10 & 2.67 & 15.81 & 3.05 \\
\hline & & IgY-PO4 (Dsp) & 9.91 & 0.76 & 7.63 & 6.28 \\
\hline \multirow{2}{*}{3} & \multirow{2}{*}{ High } & IgY-PO2 (Bt) & 26.58 & 5.01 & 16.84 & 10.94 \\
\hline & & IgY-PO4 (Dsp) & 16.21 & 1.41 & 8.71 & 6.99 \\
\hline
\end{tabular}

${ }^{a}$ Means of three replicates for each dust sample $(n=3)$

${ }^{\mathrm{b}} \mathrm{SD}$ : Standard deviation

${ }^{\mathrm{C}} \mathrm{CV}$ : Coefficient of variation inter-test

${ }^{\mathrm{d}} \mathrm{CV}$ : Coefficient of variation intra-test 
Table 3. Accuracy of the allergen detection in dust samples using IgY-PO2 and IgY-PO4, and ELISA test

\begin{tabular}{ccc}
\hline Antibody (Allergen) & Samples & Accuracy (\%) $^{\mathbf{a}}$ \\
\hline IgY-PO2 (Bt) & A & 94.65 \\
& B & 102.90 \\
& C & 86.12 \\
IgY-PO4 (Dsp) & A & 91.04 \\
& B & 80.62 \\
& C & 100.39 \\
\hline
\end{tabular}

${ }^{a}$ Means of three replicates for each dust sample $(n=3)$

\section{Discussion}

Indoor dust mite contamination evaluations have been conducted for different sampling places and geographic sites. Typically, the most used technique for this type of allergen quantification is an enzymatic immunoassay based on $\operatorname{IgG}$ monoclonal antibodies (PlattsMills, et al., 1997; Mistrello, et al., 1992). Although the ELISA test using IgG antibodies has shown good sensitivity and specificity (Liao, et al., 2013; Chapman, et al., 2001), the use of these type of antibodies has great limitations, among them, the high production cost of the assay, which limits its use in the routine indoor, workplace, and public sites monitoring and control of mite biological contamination. Developing alternative efficient, sensitive, and reproducible low-cost methods would be highly advantageous for the primary prevention of indoor mite contamination.

A method currently available on the market, the "Acarex ${ }^{\circledR}$ " test, is based on the semiquantitative determination of guanine. It is very simple and easily performed by inexperienced staff in the patient's house (Manjra, et al., 1994; Haouichat, et al., 2001). However, as guanine is a final product of purine digestion - a compound generally excreted by many arthropods including mites and spiders - this assay is not specific. Therefore, if spiders, for example, are present in the domestic environment, they could interfere with the assay (Mistrello, et al., 1992; Saijo, et al., 2007).

Recently, our group used IgY technology to produce polyclonal antibodies against dust mite group 1 allergens (cysteine protease). These antibodies showed high reactivity and sensitivity towards $D$. farinae, D. pteronyssinus, and B. tropicalis allergenic proteins including group-1 mite allergens (Egea, et al., 2018; Egea, et al., 2019). Here, we used two of these IgY antibodies (IgY-PO2 and IgY-PO4) to explore their applicability for detecting mite allergens in dust samples using an indirect ELISA test.

IgY technology has successfully been used in experimental allergology to produce antibodies against food allergens such as peanuts (Arachis hypogaea L) (Kiio \& De Meulenaer, 2012; Iqbal \& Ateeq, 2013). Moreover, other studies have applied IgY technology in the simultaneous detection of multiple food allergens such as oat proteins, Brazilian nuts, and peanuts obtaining detection limits between 1.0 and $0.1 \mu \mathrm{g} / \mathrm{g}$ and proving the viability of using them in immunochemical tests for multiple allergen detection (Blais, et al., 2003).

Here we determined that the limit of detection of IgY-PO2 and IgY-PO4 antibodies was $0.05 \mu \mathrm{g}$ of mite allergens per milliliter of extract (corresponding to $500 \mathrm{ng} / \mathrm{g}$ of dust). Our results with the dust samples showed significantly higher $(47 \mathrm{ng} / \mathrm{g}-45.53$ $\mu \mathrm{g} / \mathrm{g}$ ) allergen levels than those previously reported in the Colombian Caribbean. In this respect, in a study conducted in Cartagena (Colombia), the maximum levels of the Der p 1 and Der f 1 allergens were $109.49 \mathrm{ng} / \mathrm{g}$ and 1,600 ng/g, respectively (Mercado, et al., 1996), detected with a commercial sandwich ELISA test using IgG monoclonal antibodies. The IgY antibodies used in the present study were polyvalent in nature, which would explain their greater reactivity. Despite the use of specific synthetic peptides for 
chicken immunization, IgY antibodies recognize both group-1 allergens and others present in mites' whole body extracts as reported in a previous study (Egea, et al., 2018). It is clear to us that to establish the specific detection of mite group 1 allergens from dust it is necessary to perform calibration curves with standardized allergen extracts, which were not used in the present study.

The correspondence between the mite allergen levels (detected with the IgY antibodies) and the mite density present in the dust samples indicated that IgY antibody-based ELISA allergen measurements could be used to substitute the direct counting of mites considerably reducing analysis time. Moreover, higher intertest $(\mathrm{CV} \leq 8.71 \%)$ and intratest $(\mathrm{CV} \leq 6.99 \%)$ precision and accuracy $(80.62-100.39 \%)$ obtained with the ELISA test using IgY-PO4 substantially increase the reliability of the results. Prester, et al. (2007) reported similar results for precision (intra-assay $\mathrm{CV}<6.9 \%$, inter-assay $\mathrm{CV}<13.3 \%$ ) and accuracy $(91 \%$ to $93 \%)$ using the enzyme immunoassay with two monoclonal antibodies for the detection group-1 mite allergens (Der $\mathrm{f} 1$ and Der $\mathrm{p} 1$ ). Consequently, the detection of mite allergens using IgY antibody-based immunoassays stands out as an alternative to the currently available guanidine method, since they are specific for mite allergens and not those of other arthropods (such as cockroaches).

Future studies will be focusing on the quantification of the major Der f 1, Der p1, and Blo t 1 allergens in dust samples using specific calibration standards. The diagnostic performance and the sensitivity of the ELISA assay will be determined and compared with other commercially available reference tests. At present, several studies comparing different methods based on IgG antibodies for the detection of mite allergens in indoor environments have been published showing differences in sensibility and specificity (Saijo, et al., 2007; Rim, et al., 2016). To the best of our knowledge, presently there are no studies comparing IgG- and IgY-based tests, which would be the next step in our research.

\section{Conclusions}

Our study showed that polyclonal avian antibodies (IgY-PO2 and IgY-PO4) directed against dust mite group-1 allergens were efficient in monitoring mite levels of intramural dust samples using an indirect ELISA assay. IgYPO4 could be used for controlling mite infestation and prove beneficial to allergy-sensitive patients suffering from clinical asthma symptoms.

\section{Acknowledgments}

We would like to thank ACONDESA for supplying and donating the Hy Line Brown chickens and Elkin Navarro Quiroz for methodological support in hen immunization and development of laboratory activities. Financial support for this project was provided by the Universidad del Norte (Investigation, Development and Innovation department, DIDI), and by Colciencias (Grand 120370049094).

\section{Authors'contributions}

EE, LAB: Conception of the investigation, analysis, and interpretation of the data, critical review of the manuscript. DM: Acquisition and data analysis, writing, and critical review of the manuscript. GG: Analysis and interpretation of the data, critical review of the manuscript. SS: Acquisition and data analysis. AE: Acquisition and data analysis. ASM: Acquisition and data analysis.

\section{Conflicts of interest}

The Authors declares that there is no conflicts of interest.

\section{References}

Acuña-Cantillo, L., Moreno, A.S., Garavito, G., Egea, E., Mendoza, D.L. (2015). Prevalencia y densidad de ácaros domésticos en comunidades marginadas de dos ciudades de Colombia. Rev Cubana Invest Biomed. 34 (1): 18-26. 
Andiappan, A.K., Puan, K.J., Lee, B., Nardin, A., Poidinger, M., Connolly, J., Chew, F.T., Wang, D.Y., Rotzschke O. (2014). Allergic airway diseases in a tropical urban environment are driven by dominant mono-specific sensitization against house dust mites. Allergy. 69 (4): 501-509.

Arlian, L.G., Morgan, M.S., Goelz, J.F. (1999). Quantitation of dust mites and allergen in small dust samples. J Allergy Clin Immunol. 104 (3 Pt 1): 707-709. Doi: 10.1016/s0091-6749(99)70349-0

Asher, M.I., Stewart, A.W., Mallol, J., Montefort, S., Lai, C.K., Aït-Khaled, N., Odhiambo, J., The ISAAC Phase One Study Group. (2010). Which population level environmental factors are associated with asthma, rhinoconjunctivitis and eczema? Review of the ecological analyses of ISAAC Phase One. Respir Res. 11 (1): 8. Doi: 10.1186/1465-9921-11-8

Barrera, L.A., Egea, E., Espejo, J., Sosa, C., Navarro, E., Garavito, G., Mendoza D.L. (2016). Synthetic oligopeptides designed from mite cysteine proteases and methods for the production of polyclonal IgY antibodies for the detection of intradomiciliary mites. Patent US 9.416,163 B2. United States. Accessed on: August 2, 2018. Available at: https://patentimages.storage. googleapis.com/af/d6/dd/b5456b9d46b5eb/US9416163.pdf

Blais, B., Gaudreault, M., Phillippe, L.M. (2003). Multiplex enzyme immunoassay system for the simultaneous detection of multiple allergens in foods. Food Control. 14 (1): 43-47.

Chapman, M.D., Tsay, A., Vailes, L.D. (2001). Home allergen monitoring and control - improving clinical practice and patient benefits. Allergy. 56 (7): 604-610.

Collof, M.J., Spieksma, F. (1992). Pictorial keys for the identification of domestic mites. Clin Exp Allergy. 22: 823-830.

Dennis, R., Caraballo, L., García, E., Caballero, A., Aristizábal, G., Córdoba, H., Rodriguez, M.N., Rojas, M.X., Orduz, C., Cardona, R., Blanco, A., Egea, E., Verbel, C., Cala L.L. (2004). Asthma and other allergic conditions in Colombia: a study in 6 cities. Ann Allergy Asthma Immunol. 93 (6): 568-574.

Dennis, R.J., Caraballo, L., García, E., Rojas, M.X., Rondón, M.A., Pérez, A., Aristizábal, G., Peñaranda, A., Barragán, A.M., Ahumada, V., Jiménez, S. (2012). Prevalence of asthma and other allergic conditions in Colombia 2009-2010: a cross-sectional study. BMC Pulm Med. 12: 17. Doi: 10.2217/14622416.9.4.453.

Drake, K.A., Galanter, J.M., Burchard, E.G. (2008). Race, ethnicity and social class and the complex etiologies of asthma. Pharmacogenomics. 9 (4): 453-462.

Egea, E., Mendoza, D., Garavito, G., Espejo, A., Lizaraso, L.M., Navarro, E., Barrera L.A. (2018). IgY específicos anti-alérgenos del grupo 1 de ácaros del polvo doméstico inducidos por oligopéptidos sintéticos no glicosilados. Biomédica. 38: 232-243. Doi: 10.7705/ biomedica.v38i0.3689

Egea, E., Mendoza, D., Garavito, G., Saavedra, S., Gómez, H., Sanjuan, M. (2019). Nanogold - IgY antibodies. An immunoconjugated for the detection of house dust mite (Dermatophagoides) allergens. J Immunol Methods. 464: 15-21. Doi: 10.1016/j.jim.2018.08.013

Environmental Protection Agency (EPA). Sampling House Dust for Lead: Basic Concepts and Literature Review, Final Report, EPA 747-R-95-007. Washington D.C., United States. 1995. Accessed on: October 25, 2015. Available at: www.epa.gov/sites/production/files/documents/ r95-007.pdf

Halken, S. (2004). Prevention of allergic disease in childhood: clinical and epidemiological aspects of primary and secondary allergy prevention. Pediatr Allergy Immunol. 15 (Suppl 16): 9-32.

Haouichat, H., Pauli, G., Ott, M., Bessot, J.C., de Blay, F., Verol, A., Bessot, J.C. (2001). Controlling Indoor Mite Exposure: The Relevance of the Acarex Test. Indoor Built Environ. 10 (2): 109-115.

Huss, K., Adkinson, N.F., Eggleston, P.A., Dawson, C., Van Natta, M.L., Hamilton, R.G. (2001). House dust mite and cockroach exposure are strong risk factors for positive allergy skin test responses in the Childhood Asthma Management Program. J Allergy Clin Immunol. 107 (1): 48-54.

Iqbal, A. \& Ateeq, N. (2013). Effect of processing on the detectability of peanut protein by ELISA. Food Chem. 141 (3): 1651-1654.

Kamble, S. \& Bharmal, M. (2009). Incremental direct expenditure of treating asthma in the United States. J Asthma. 46 (1): 73-80.

Kiio, J.N. \& De Meulenaer, B. (2012). Immunological detection of peanut (Arachis hypogeal L) proteins using chicken antibodies. Food Agr Immunol. 23 (3): 217-226.

Liao, E.C., Lin, Y.H., Tsai, J.J. (2013). Detection of group 2 Dermatophagoides pteronyssinus allergen for environmental monitoring of dust mite infestation. Biosci Trends. 7 (2): 82-88. 
Liu, X., Zheng, P., Zheng, S.G., Zhai, Y., Zhao, X., Chen, Y., Xiangwei, W.Z., Cai, C., Wu, Z., Huang, Z., Zou, X., Liao, C., Sun, B. (2019). Co-sensitization and cross-reactivity of Blomia tropicalis with two Dermatophagoides species in Guangzhou, China. J Clin Lab Anal. 33 (9): [e22981]. Doi: 10.1002/jcla.22981

Londoño-Trujillo, D., Celis-Preciado, C.A. (2014). Medición de costos indirectos en pacientes colombianos con asma. Revista Colombiana De Neumología. 26 (1): 12-18. Doi: 10.30789/ rcneumologia.v26.n1.2014.54

Manjra, A., Berman, D., Weinberg, E.G., Gous, E., Potter, P.C. (1994). Comparison between the Acarex test and a Der $p 1$ ELISA for the detection of house-dust mites in the homes of asthma sufferers. S Afr Med J. 84 (4): 220-222.

Marks, G.B. (1998). House dust mite exposure as a risk factor for asthma: benefits of avoidance. Allergy. 53 (48 Suppl): 108-114.

Del Castillo-Castilla, L., Mendoza-Meza, D. L., Lozano-Socarrás, S., Jaimes-Sanabria, M. B., Pedrozo-Pupo, J., Abello-Gámez, L. (2008). Factores de riesgo asociados con asma alérgica en niños de 4 a 16 años de Santa Marta, Colombia. Duazary. 5 (1): 9-14. Doi: $10.21676 / 2389783 X .55$

Mendoza, D.L., Ruiz, T., Lagares, A., Garavito, G., Egea, E. (2011). Caracterización de la actividad alergénica y enzimática de extractos somáticos producidos a partir de cultivos in vitro del ácaro Dermatophagoides farinae. Salud Uninorte. 27 (1): 11-21.

Mercado, D., Puerta, L., Caraballo, L. (1996). Niveles de alergenos de ácaros en el polvo de habitación en Cartagena, Colombia. Biomédica. 16: 307-314.

Milián, E., Díaz, A.M. (2004). Allergy to house dust mites and asthma. P R Health Sci J. 23 (1): 47-57.

Mistrello, G., Roncarolo, D., Ottoboni, F., Rigamonti, I. (1992). Quantitative determination of Der p I allergen levels in allergenic extracts and house-dust samples. Aerobiologia. 8 (3): 429-434.

Morgan, W.J., Crain, E.F., Gruchalla, R.S., O'Connor, G.T., Kattan, M., Evans, R. 3rd., Stout, J., Malindzak, G., Smartt, E., Plaut, M., Walter, M., Vaughn, B., Mitchell, H. (2004). Inner-City Asthma Study Group. Results of a home-based environmental intervention among urban children with asthma. N Engl J Med. 351 (11): 1068-1080.

Mukherjee, A.B. \& Zhang, Z. (2011). Allergic asthma: influence of genetic and environmental factors. J Biol Chem. 286 (38): 32883-32889. Doi: 10.1074/jbc.R110.197046

Paufler, P., Gebel, T., Dunkelberg, H. (2001). Quantification of house dust mite allergens in ambient air. Rev Environ Health. 16 (1): 65-80.

Platts-Mills, T.A., Vervloet, D., Thomas, W.R., Aalberse, R.C., Chapman, M.D. (1997). Indoor allergens and asthma: report of the Third International Workshop. J Allergy Clin Immunol. 100 (6): S2-24.

Portnoy, J., Miller, J.D., Williams, P.B., Chew, G.L., Miller, J.D., Zaitoun, F., ... Wallace, D. (2013). Environmental assessment and exposure control of dust mites: a practice parameter. Ann Allergy Asthma Immunol. 111: 465-507. Doi: 10.1016/j.anai.2013.09.018

Prester, L., Brcić Karaconji, I., Macan, J. (2007). Determination of mite allergens in house dust using the enzyme immunoassay. Arh Hig Rada Toksikol. 58 (4): 413-419. Doi: 10.2478/ v10004-007-0034-2

Rappaport, H. \& Bonthapally, V. (2012). The Direct Expenditures and Indirect Costs Associated with Treating Asthma in the United States. J Aller Ther. 3 (2): 1-8.

Rim, J.H., Park, B.G., Kim, J.H., Kim, H.S. (2016). Comparison and clinical utility evaluation of four multiple allergen simultaneous tests including two newly introduced fully automated analyzers. Pract Lab Med. 21 (4): 50-61. Doi: 10.1016/j.plabm.2016.01.002

Rodríguez-Martínez, C.E., Sossa-Briceño, M.P., Castro-Rodríguez, J.A. (2017). Análisis de costoutilidad de la administración de corticoesteroides inhalados una vs. dos veces al día para el tratamiento de pacientes pediátricos con asma persistente. Rev.Medica.Sanitas. 20 (3): 139-151.

Saijo Y, Nakagi Y, Sugioka Y, Ito T, Endo H, Kuroda H, Yoshida, T. (2007). Comparative study of simple semiquantitative dust mite allergen tests. Environ Health Prev Med. 12 (5): 187-192.

Smiley, R.L. \& Gorham, J.R. (1991). Insect and mite pests in food: An illustrated key. Deparment of Agriculture, Agricultural Research Service, Washington, DC. 1: 3-43.

Vojta, P.J., Randels, S.P., Stout, J., Muilenberg, M., Burge, H.A., Lynn, H., Mitchell, H., O'Connor G.T., Zeldin, D.C. (2001). Effects of physical interventions on house dust mite allergen levels in carpet, bed, and upholstery dust in low-income, urban homes. Environ Health Perspect. 109 (8): 815-819.

Winn, A.K., Salo, P.M., Klein, C., Sever, M.L., Harris, S.F., Johndrow, D., Crockett, P.W., Cohn, R.D., Zeldin, D. (2016). Efficacy of an in-home test kit in reducing dust mite allergen levels: results of a randomized controlled pilot study. J Asthma. 53 (2): 133-138. 